\title{
Comparison of CA 125, CA 72-4, Risk of Malignancy Index and DePriest Scoring System in the Differentiation Between Benign and Malignant Adnexal Masses
}

\section{Benign ve Malign Adneksiyal Kitle Ayrımında CA 125, CA 72-4, Malignite Risk Indeksi ve DePriest Skorlama Sisteminin Karşılaştırması}

\author{
Haydar Kaya ${ }^{1 \oplus}$, Kemal Sandal ${ }^{2}$, Ahmet Gocmen $^{3} \oplus$, İbrahim Yilmaz ${ }^{4}$ \\ ${ }^{1}$ Department of Gynecology and Obstetrics, Saruhanlı State Hospital, Manisa, Turkey \\ 2 Department of Gynecology and Obstetrics, Saglik Bilimleri Üniversity Sancaktepe Şehit Prof. Dr. Ilhan Varank Training and Research \\ Hospital, Istanbul, Turkey \\ ${ }^{3}$ Department of Gynecology and Obstetrics, Memorial Hospital, Istanbul, Turkey \\ ${ }^{4}$ Medical Biochemistry Laboratory, Haseki Training and Research Hospital, Istanbul, Turkey
}

Received: 10 December 2019 / Accepted: 21 March 2020 / Publication date: 26 June 2020

Cite as: Kaya H, Sandal K, Gocmen A, Yilmaz I. Comparison of CA 125, CA 72-4, risk of malignancy index and DePriest scoring system in the differentiation between benign and malignant adnexal masses. Med J Bakirkoy 2020;16(2):95-102.

\section{ABSTRACT}

Objective: The aim of this study is to compare prospectively CA 125, CA72-4, risk of malignancy index (RMI) and DePriest morphological scoring system in differentiation between benign and malignant adnexal masses.

Method: Data of 116 cases operated due to adnexal mass were analyzed. Blood samples were taken from the patients for CA 125 and CA 72-4 before the operation. In ultrasonographic examination, risk of malignancy index (RMI) and DePriest morphological scoring system were used. SPSS 22.0 (Statistical Package for Social Sciences) for Windows program was used for analyses.

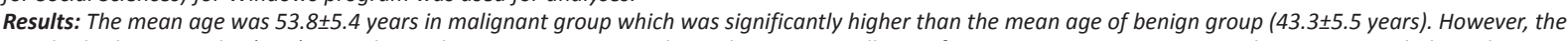
weight, body mass index (BMI), gravidity and parity rates were similar and not statistically significant. CA 125, CA 72-4, RMI and DePriest morphological scoring system were significantly higher in malignant group than benign group $(p<0,05)$. Pelvic pain was the most common admission complaint (56\%: $n=65)$ followed by referral from another hospital (32.7\%: $n=38)$. Benign masses were reported in $88(75,9 \%)$, and malignant masses in $28(24,1 \%)$ of 116 patients. Endometrioma $(n=19,16,3 \%)$ and serous cystadenoma $(n=19,16,3 \%)$ were the most common pathological entities in the benign group, while serous cystadenocarcinoma $(n=13$ $11,2 \%)$ was the most common pathological entity in the malignant group.

Conclusion: CA72-4 did not have enough effectivity to predict the results of pathology in adnexal masses because of its low sensitivity. Significant efficiency of RMI and CA 125 were monitored. DePriest morphological scoring system was found to be more effective than CA 125, CA 72-4 and RMI in differentiation between benign, and malignanat adnexal masses.

Keywords: CA 125, CA 72-4, risk of malignancy index, adnexal mass

öz

Amaç: Bu çalışmada CA 125, CA 72-4, malignite risk indeksi (RMI) ve DePriest morfolojik skorlama sisteminin benign-malign adneksiyal kitle ayrımında prospektif olarak karşılaştırılması amaçlanmıştır.

Yöntem: Adneksiyel kitle nedeniyle opere olan 116 hastanın verileri incelendi. Operasyon öncesi hastalardan CA 125 ve CA 72-4 için kan alındı. USG değerlendirmesinde malignite risk indeksi (RMI) ve DePriest morfolojik skorlama sistemi kullanıldı. Analizlerde SPSS 22.0 (Statistical Package for Social Sciences) programından yararlanıldı.

Bulgular: Malign hasta grubunda yaş ortalaması 53,8 85,4 saptandı ve benign gruptaki hastaların yaş ortalamasına $(43,3 \pm 5,5)$ göre istatistiksel olarak anlamlı yüksekti. Ancak her iki grubun da kilo, VKi, gravida ve parite oranları benzerdi ve istatistiksel olarak anlamlı değildi. Malign olan grupta CA 125 ve CA $72-4$ değerleri, RMI ve DePriest skoru benign olan gruptan anlamlı $(p<0,05)$ olarak daha yüksekti. Hastaneye gelis sikayetlerinde $\% 56(n=65)$ ile ilk sırada pelvik ağrı gelirken onu \%32,7 ( $n=38$ ) ile başka merkezden referans ile yönlendirilme izlemekteydi. Hastaların \% 75,9'unda $(n=88)$ histopatolojik değerlendirmede sonuçların benign, $\% 24,1^{\prime}$ inde $(n=28)$ ise malign olduğu görüldü. Benign grupta en sık $(n=19 \% 16,3)$ endometrioma ve $(n=19 \% 16,3)$ seröz kistadenom görülürken, malign grupta ise seröz adenokarsinom en sık ( $n=13 \% 11,2)$ saptanan over tümörü oldu.

Sonuç: Sensitivitesinin düşük olması sebebiyle CA72-4 adneksiyel kitlelerde patoloji sonucunu öngörmede yeterli bulunmamıştır. RMI ve CA 125'in anlamlı etkinliği gözlenmiştir. Çalışma sonucunda malignite öngörüsünde tek başına değerlendirildiğinde Depriest skorlama sisteminin CA 125, CA 72-4 ve RMI skorlama sisteminden daha etkin olduğu izlenmisțir.

Anahtar kelimeler: CA 125, CA 72-4, malignite risk indeksi, adneksiyal kitle

Corresponding Author:

haydartip@gmail.com
H. Kaya 0000-0001-9021-5125

K. Sandal 0000-0002-3736-0523

A. Gocmen 0000-0002-0839-7490

i. Yilmaz 0000-0003-4719-0246

(C) Telif hakkı Sağlık Bilimleri Üniversitesi Bakırköy Dr. Sadi Konuk Eğitim ve Araştırma Hastanesi'ne aittir. Logos Tıp Yayıncılık tarafından yayınlanmaktadır. Bu dergide yayınlanan bütün makaleler Creative Commons Atff-GayriTicari 4.0 Uluslararası Lisansı ile lisanslanmıştır.

(c) Copyright Health Sciences University Bakırköy Sadi Konuk Training and Research Hospital. This journal published by Logos Medical Publishing.

Licenced by Creative Commons Attribution-NonCommercial 4.0 International (CC BY-NC 4.0) 


\section{INTRODUCTION}

Adnexal masses develop from the uterus, ovary, tuba or surrounding tissue. They are benign., and largely ovarian neoplasms. Surgery is applied to $5-10 \%$ of women throughout their life due to ovarian neoplasia. Malignancy is detected in $13-21 \%$ of these women ${ }^{(1)}$. According to the United States (USA) data, approximately 300,000 women are hospitalized each year due to adnexal masses (2). The most important preoperative issue is to evaluate the possibility of ovarian cancer, except for patients who come with emergency findings. Ovarian cancer is the leading cause of gynecological cancer-related deaths. Most of the patients are in their postmenopausal period. The incidence of ovarian cancer in women aged 20-49 is 1.6-16 / 100000 and 0.7-14 / 100000 in adolescents under 20 years of age ${ }^{(3)}$. Ovarian cancer is the seventh most common cancer and the fifth most common cause of death among all cancers in women, according to USA data ${ }^{(4)}$.

Many laboratory examinations, imaging methods or their combined use have been determined or are currently being studied in order to evaluate patients with adnexal masses in terms of presence of malignancy. In the embedding method, tumor diameter (>50 mm), thick septa, wall thickness, solid component, contrast enhancement, invasion, acid and bilaterality are used in the distinction of malignancy, and the presence of 3 or more criteria is considered significant ${ }^{(5)}$. CA 125 , a glycoprotein antigen, is found in the celilomic epithelium, amniotic fluid, pleura, peritoneum, pericardium, bronchial and cervical secretion of normal adults. While it is not found in normal adult ovarian tissue, it is detected in $80 \%$ of epithelial ovarian cancers ${ }^{(6)}$. CA $72-4$ is a glycoprotein surface antigen found in colon, gastric and ovarian cancers. It increases in $67 \%$ of ovarian cancers and its sensitivity is higher for mucinous tumors ${ }^{(7)}$. The malignancy risk index (RMI) published by Jacobs et al. in 1990 is known as a model used in the differentiation between malignant, and benign adnexal masses and in which ultrasound, RMI score, serum CA 125 and menopausal status are evaluated in combination ${ }^{(8)}$. Another scoring system is DePriest's 3-criteria morphological scoring system. In this system, by recording the ovarian volume, cyst wall structure and septa structure, a prediction can be made without using additional laboratory methods (9). In our study, we aimed to compare CA 125, CA 72-4, malignancy risk index (RMI) and DePriest morphological scoring systems prospectively.

\section{MATERIAL and METHOD}

Ethics committee approval was obtained from the Ethics Committee of Medeniyet University Göztepe Training and Research Hospital. In this study, 126 patients who were scheduled for an operation with a diagnosis of adnexal mass between September 2014 and December 2015 in the Obstetrics and Gynecology Clinic were evaluated. The study was designed as a prospective cohort study. The nonpregnant patients without a biopsy history from the adnexal mass, or undergoing ovulation induction process and voluntarily giving consent to the study were included in the study. Patients with a history of malignancy were excluded. Voluntary informed consent was obtained from a total of 126 patients. Ten patients were excluded from the study. Blood tests of 4 patients were taken inappropriately, 4 patients refused to undergo surgery, 1 patient had a history of colon cancer, 1 patient had a history of rectal cancer. Age, body mass index (BMI), pregnancy and number of births (parities) CA 125 and CA 72-4 values and ultrasonography findings of 116 patients were recorded in accordance with RMI and DePriest scoring systems.

\section{Technical data}

In the ultrasonographic evaluation, 5-2 Mhz convex abdominal and 9-5 Mhz endovaginal probes were used with Sonoscape S11 3D ultrasound device. All ultrasonographic evaluation was done by a single clinician. RMI score; The ultrasound score (U), menopause score (M) and serum CA 125 values were recorded and calculated with the formula $[\mathrm{U}] \times[\mathrm{M}] \mathrm{x}$ [CA 125] (Table 1). Two hundred or more values were interpreted in favor of malignant mass. DePriest score was determined by evaluating ovarian volume, cyst wall structure and septa structure (Table 2). Ovarian volume was calculated with the ellipsoid formula (length $x$ height $x$ width $x$ 0.523). If total score calculated for volume + cyst wall + septa structure score was $\geq 5$, then the results were evaluated in favor of a malignant mass. After 8-12 hours of fasting, blood samples were drawn into anticoagulant- 
H. Kaya et al, Comparison of CA 125, CA 72-4, Risk of Malignancy Index and DePriest Scoring System in the Differentiation Between Benign an Malignant Adnexal Masses

Table 1. Risk of malignancy index (RMI).

\begin{tabular}{lc}
\hline & RMI 1* \\
\hline Menopausal condition (M) & $\begin{array}{c}\text { Premenopausal: } 1 \\
\text { Postmenopausal: } 3\end{array}$ \\
Ultrasonography findings (U) & \\
Multilocular cyst & No feature: 0 \\
Solid field & 1 feature: 1 \\
Bilaterality & $>1$ feature: 3 \\
Ascites & \\
Metastasis & Serum CA 125 level \\
Serum CA 125 & \\
\hline
\end{tabular}

${ }^{*}$ RMI 1: The risk of malignancy index, Jacobs et al. published in 1990.

free gel tubes. After waiting for no more than 1 hour at room temperature, their serums were separated by centrifugation at $2500 \mathrm{rpm}$ for 10 minutes.

The obtained serums were portioned into $1.5 \mathrm{~mL}$ Eppendorf tubes and stored at $-80^{\circ} \mathrm{C}$ until analysis.

All analyzes were performed simultaneously. The laboratory team conducting the studies were blinded about patient information. Serum CA 125 and CA 72-4 measurements were made using the Modular E170 analyzer (Roche Diagnostics GmbH, Germany) by electrochemiluminescence method. Normal values for CA 125 (<35 U/ml), CA 72-4: (0-4 U/mL) were taken into consideration during assessments.. The pathology results of the patients after surgery were compared to the measurements of CA 125, CA 72-4 in blood samples stored at -80 degrees, with the RMI and DePriest scoring system.

\section{Statistics}

Mean, standard deviation, median lowest, highest, frequency and ratio values were used in the descriptive statistics of the data. The normality of distribution of variables was evlauated by Kolmogorov -Smirnov test. In the analysis of quantitative data, Mann-Whitney $\mathrm{U}$ test was used. Chi-square test was used in the analysis of qualitative data. SPSS 22.0
(Statistical Package for Social Sciences) program was used in the analysis. The level of statistical significance was set at $p<0.05$.

\section{RESULTS}

In the evaluation of data of 116 patients, the mean age was $45.9 \pm 11.9$ years ( $\min 21-\max 70$ ). The mean age of the malignant group was $53.8 \pm 5.4$ years which was statistically significantly higher than the mean age of the patients in the benign group (43.3 \pm 5.5 years). However, the weight, BMI, gravida and parity ratios of both groups were similar and were not statistically significant. CA 125, CA 72-4, $\mathrm{RMI}$ and DePriest scores in the malignant group were significantly higher $(p<0.05)$ than the benign group. Demographic characteristics, CA 125, CA 72-4 values, RMI and DePriest scores of the patients according to benign and malignant groups are given in Table 3.

Pelvic pain was the most frequent admission complaint $(56 \%:=65)$ followed by referral from another center (32.7\%:n=38). Adnexal mass was detected incidentally in 6 patients $(5.1 \%)$ in routine gynecological examination. Mass, amenorrhea and vaginal bleeding were less likely causes of application to the hospital. In histopathological evaluation in $75.9 \%$ $(n=88)$ of the patients, benign, and in $24.1 \%(n=28)$ patients malignant (borderline ovarian tumor was included in the malignant group) masses were detected. In the benign group ( $n=19$ 16.3\%), endometrioma and ( $n=19$ 16.3\%) serous cystadenoma were the most common pathologies, while in the malignant group, serous adenocarcinoma was the most common ( $n=13 \quad 11.2 \%$ ) ovarian tumor. The patients in the malignant group were in Stages 1 $(n=18: 15.5 \%), 3$ ( $n=9: 7.8 \%)$, and 4 ( $n=1: 0.9 \%)$. Other benign pathological diagnoses were mature cystic teratoma, follicle cyst, corpus luteum cyst, mucinous cystadenoma, leiomyoma, struma ovarii,

Table 2. DePriest morphological scoring system.

\begin{tabular}{|c|c|c|c|c|c|}
\hline Parameters & 0 & 1 & 2 & 3 & 4 \\
\hline Volume & $<10 \mathrm{~cm}^{3}$ & $10-50 \mathrm{~cm}^{3}$ & $50-200 \mathrm{~cm}^{3}$ & $200-500 \mathrm{~cm}^{3}$ & $>500 \mathrm{~cm}^{3}$ \\
\hline Cyst wall (thickness) & Smooth $<3 \mathrm{~mm}$ & Smooth $\geq 3$ mm & Papillary bulge $<3 \mathrm{~mm}$ & Papillary bulge $\geq 3 \mathrm{~mm}$ & dominant solid \\
\hline Septa structure (thickness) & No septa & Thin septa $<3 \mathrm{~mm}$ & Thick septa 3-10 mm & Solid septa $\geq 10$ mm & dominant solid \\
\hline
\end{tabular}

${ }^{*} R M I$ 1: The risk of malignancy index, Jacobs et al. published in 1990 
Table 3. Demographic characteristics, CA 125, CA 72-4 values, risk of malignancy index (RMI) and DePriest scores of patients in benign and malignant groups.

\begin{tabular}{|c|c|c|c|c|c|c|}
\hline \multirow[b]{3}{*}{ Weight } & \multicolumn{3}{|c|}{ Benign } & \multicolumn{3}{|c|}{ Malignant } \\
\hline & \multirow{2}{*}{$\begin{array}{c}\text { Mean } \pm \text { s.d } \\
63,8 \pm 8,8\end{array}$} & \multicolumn{2}{|c|}{ Med (min-max) } & \multirow{2}{*}{$\begin{array}{c}\text { Mean } \pm \text { s.d } \\
67 \pm 6\end{array}$} & \multicolumn{2}{|c|}{ Med (min-max) } \\
\hline & & 65 & $50-82$ & & 66 & $53-108$ \\
\hline BMI* & $25,4 \pm 3,8$ & 25 & $18,4-35,6$ & $26 \pm 3,7$ & 26 & $20-39,7$ \\
\hline Age & $43,3 \pm 5,5$ & 45 & $21-68$ & $53,8 \pm 5,4$ & 57 & $36-70$ \\
\hline Gravida & $3,1 \pm 3,2$ & 2 & $0-17$ & $3 \pm 2,6$ & 2 & $0-12$ \\
\hline Parity & $2 \pm 2,7$ & 1 & $0-10$ & $2,2 \pm 2,1$ & 3 & $0-7$ \\
\hline CA 125 & $59,1 \pm 134,3$ & 20 & $5,8-901$ & $261,4 \pm 407$ & 77,7 & $6,5-1719$ \\
\hline CA 72-4 & $2,1 \pm 2,8$ & 1,1 & $0,7-17,1$ & $15,5 \pm 56,1$ & 2,0 & $0,8-299,8$ \\
\hline DePriest score & $3,2 \pm 2,4$ & 2,0 & $0,0-10,0$ & $7,3 \pm 1,8$ & 8,0 & $5,0-10,0$ \\
\hline RMI† & $123 \pm 291$ & 43 & $0-2303$ & $1502 \pm 2446$ & 380 & $27-10764$ \\
\hline \multicolumn{7}{|l|}{ Menopausal condition } \\
\hline Premenopausal & $6472,7 \%$ & & & $1035,7 \%$ & & \\
\hline Postmenopausal & $24 \quad 27,3 \%$ & & & $1864,3 \%$ & & \\
\hline
\end{tabular}

*BMI: Body mass index, +RMI: Risk of malignancy index

Table 4. Comparison of CA 125, CA 72-4, risk of malignancy index and DePriest scores.

\begin{tabular}{|c|c|c|c|c|c|c|c|c|}
\hline & Benign & Malignant & Sensitivity & PPV* & Specificity & NPV+ & Kappa & p \\
\hline \multicolumn{9}{|l|}{ CA 125} \\
\hline$(-)$ & 63 & 8 & $71,4 \%$ & $44,4 \%$ & $71,5 \%$ & $88,7 \%$ & 0,088 & 0,002 \\
\hline$(+)$ & 25 & 20 & & & & & & \\
\hline \multicolumn{9}{|l|}{ CA 72-4 } \\
\hline$(-)$ & 79 & 20 & $28,6 \%$ & $47,1 \%$ & $89,8 \%$ & $79,8 \%$ & 0,212 & 0,017 \\
\hline$(+)$ & 9 & 8 & & & & & & \\
\hline \multicolumn{9}{|l|}{ RMI‡ } \\
\hline$<200$ & 78 & 10 & $64,3 \%$ & $64,3 \%$ & $88,6 \%$ & $88,6 \%$ & 0,529 & 0,000 \\
\hline$\geq 200$ & 10 & 18 & & & & & & \\
\hline \multicolumn{9}{|c|}{ DePriest score } \\
\hline$<5$ & 68 & 0 & $100 \%$ & $58,3 \%$ & $77,3 \%$ & $100 \%$ & 0,621 & 0,000 \\
\hline$\geq 5$ & 20 & 28 & & & & & & \\
\hline
\end{tabular}

*PPV: Positive predictive value. +NPV: Negative predictive value, $¥ R M I$ : Risk of malignancy index

fibrotechoma, tuboovarian abscess, hemorrhagic cyst and ovarian torsion. Other malignant diagnoses were endometrioid adenocarcinoma, mucinous adenocarcinoma, borderline serous tumor, borderline mucinous tumor, granulosa cell tumor, Sertoli-Leydig cell tumor, Brenner tumor. Although diagnostic sensitivity of CA 125 was $71.4 \%$, its diagnostic specificity, and the positive predictive values were $44.4 \%$ and $71.5 \%$, respectively $(p=0.002)$. The positive, and negative predictive values of CA $72-4$ were $47.1 \%$ and $79.8 \%$, respectively $(p=0.017)$. Significant $(p=0,000)$ and strong efficacy of cut- off values of $\geq 200$ for RMl scores in the prediction of malignant and benign group of patients were observed. As cut-off value, De Priest score of 5 points was found to be statistically significant and the highest index in the differential diagnosis of malignancy with $100 \%$ sensitivity, $77.3 \%$ specificity, 58.3\% PPV and 100\% NPV ( $p=0,000)$. The results are given comparatively in Table 4 .

Forty women (36.2\%) were in the postmenopausal period, while $57.1 \%$ of patients with RMI score of $\geq$ 200 and $52 \%$ of patients with DePriest score of $\geq 5$ were in the postmenopausal period. These rates were found to be $60 \%$ and $64 \%$ in patients with CA $125 \geq 35$ and CA $72-4 \geq 4$, respectively. As a statistically significant finding, $64.7 \%$ of malignant group of patients consisted of postmenopausal women. Comparison of benign and malignant groups by menopausal status is given in Table 5 .

Eight patients with CA 125 false negative results had 
H. Kaya et al, Comparison of CA 125, CA 72-4, Risk of Malignancy Index and DePriest Scoring System in the Differentiation Between Benign an Malignant Adnexal Masses

Table 5. Comparison of benign and malignant groups by menopausal status.

\begin{tabular}{|c|c|c|c|c|}
\hline & \multicolumn{2}{|c|}{ Benign } & \multicolumn{2}{|c|}{ Malignant } \\
\hline & Premenopausal & Postmenopausal & Premenopausal & Postmenopausal \\
\hline \multicolumn{5}{|l|}{ CA 125} \\
\hline$(-)$ & 53 & 10 & 3 & 5 \\
\hline$(+)$ & 15 & 10 & 3 & 17 \\
\hline \multicolumn{5}{|l|}{ CA 72-4 } \\
\hline$(-)$ & 60 & 19 & 8 & 12 \\
\hline$(+)$ & 4 & 5 & 2 & 6 \\
\hline \multicolumn{5}{|l|}{ RMI‡ } \\
\hline$<200$ & 58 & 20 & 4 & 6 \\
\hline$\geq 200$ & 6 & 4 & 6 & 12 \\
\hline \multicolumn{5}{|c|}{ DePriest score } \\
\hline$<5$ & 51 & 17 & 0 & 0 \\
\hline$\geq 5$ & 13 & 7 & 10 & 18 \\
\hline
\end{tabular}

*RMI: Risk of malignancy index

Table 6. Comparison of false positives and false negatives by menopausal status.

\begin{tabular}{lcccc}
\hline & \multicolumn{1}{c}{ False } & Positivity & False & Negativity \\
\cline { 2 - 5 } & Premenopausal & Postmenopausal & Premenopausal & Postmenopausal \\
\hline CA 125 & 23 & 2 & 4 & 4 \\
CA 72-4 & 8 & 1 & 7 & 13 \\
RMI* & 6 & 4 & 4 & 6 \\
DePriest & 13 & 7 & 0 & 0 \\
\hline
\end{tabular}

*RMI: Risk of malignancy index

borderline serous tumors $(n=3)$, serous carcinoma $(n=2)$, granulosa cell tumors $(n=2)$, and Sertoli-Leydig cell tumor ( $n=1)$, while 17 of 25 patients with false positivie results were detected to have endometriomas. Eight of 20 patients with CA 72-4 with false negative results were serous carcinoma and in 5 of 9 patients who gave false positive results, had received the diagnosis of endometrioma. Serous carcinoma was seen in 3 of 10 patients with false negative RMl results, and in 7 of 10 patients with false positive results were diagnosed as endometrioma. While the DePriest scoring system did not give false negative results, the most common diagnoses of 20 patients with false positive results were leiomyoma in 5, serous cystadenoma in 4 , and mucinous cystadenoma in 4 patients. Twenty-three of 25 patients with false positive CA 125,8 of 9 patients with false positive CA 72-4, 6 of 10 patients with alse positive RMI, and 13 of 20 patients with false positive DePriest scores were observed in premenopausal period.
Comparison of false positivity and false negativity rates according to menopausal status is given in Table 6.

While 16 of 19 patients diagnosed with endometrioma were found CA 125 positive, RMI was positive in 6 patients. DePriest scoring system was found positive in 8 of 8 patients diagnosed with borderline tumor. CA 125 and RMI were positive in 5 patients. The results are given in Table 7.

Table 7. Methods used in the diagnosis of endometrioma and borderline ovarian tumors.

\begin{tabular}{lcc}
\hline Method & $\begin{array}{c}\text { Endometrioma } \\
\text { (n:19) }\end{array}$ & $\begin{array}{c}\text { Borderline ovarian tumor } \\
\text { (n:8) }\end{array}$ \\
\hline CA 125 & 16 & 5 \\
CA 72-4 & 5 & 1 \\
RMI* & 6 & 5 \\
DePriest score & 0 & 8 \\
\hline
\end{tabular}

*RMI: Risk of malignancy index 
In our study, for the diagnosis of endometrioma, CA 125 , and for the diagnosis of borderline tumor, DePriest scoring system come to the fore. If the four methods are combined, the lowest positive predictive value was $38.8 \%$ and the negative predictive value was $100 \%$ if any method is positive. Considering that $100 \%$ negative predictive value was determined when the DePriest scoring system was used, the combination of four methods does not provide an extra diagnostic advantage.

\section{DISCUSSION}

Being able to make differential diagnosis of adnexal masses preoperatively is very important for the effectiveness of the treatment to be applied. In the patient group included in the study, a correlation was observed between age and menopausal status and the possibility of malignancy which is consistent with the literature. There was no significant difference between BMI, gravida and parity values. The reason for this is that the patient distribution cannot be homogenized due to the limited sample size and our center being a tertiary oncology center as well as accepting reference patients as an advanced center for pelvic pain and endometriosis. While pelvic pain $(56 \%, n=65)$ and referral from another center $(32.7 \%$, $\mathrm{n}=38$ ) were the most common causes of admission to our clinic, in the another study the most common reasons for admission were pelvic pain and vaginal bleeding or menstrual irregularity ${ }^{(10)}$.

The lowest, highest, and mean RMI scores for were 0,10764 , and $456 \pm 1349$, respectively. RMI scores below, and above were 200 were estimated for 88 (75.9\%), and $28(24.1 \%)$ patients, respectively.While the mean RMI score was $123 \pm 291$ in the benign group, it was $1502 \pm 2446$ in the malignant group $(p=0.000)$. In our study, we also determined the sensitivity $(64.3 \%)$, specificity $(88.6 \%)$, positive $(64.3 \%)$ and negative (88.6\%) predictive values of RMI scores. In 2004, in a case series consisting of 100 patients, Obeidat et al., found the sensitivity, specificity, positive and negative predictive values of RMI as 90,89 , 96 and $78 \%$ respectively ${ }^{(11)}$. In the study of Andersen et al. performed with 180 patients in 2003, the sensitivity (70.6\%), specificity (87.7\%), positive $(66.1 \%)$ and negative (89.8\%) predictive values for RMI were stated as indicated ${ }^{(12)}$. In the study of Tingulstad et al. performed with 365 patients, sensitivity specificity positive and negative predictive values were detected as $71,92,69$, and $92 \%$, respectively ${ }^{(13)}$. In our study, we found that our data were compatible with the literature.

In our study, the DePriest scores ranged from 0 to 10 (mean: 4.2 \pm 2.9 , median: 4.0 ). In the study, 68 (58.6\%) patients had $<5$, and $48(41.4 \%)$ patients had $>5$ points. While the mean DePriest score was $3.2 \pm 2.4$ in the benign patient group, it was $7.3 \pm 1.8$ in the malignant group. In the malignant group, the DePriest score was significantly higher $(p=0,000)$ than the benign group. The sensitivity $(100 \%)$, specificity (77.3\%), positive (58.3\%), and negative (100\%). predictive values for the DePriest cut-off score of 5 points in predicting the pathology results were as indicated in parentheses. There was a significant (Kappa: $0.621 / p=0.000$ ) agreement between DePriest scores and pathology results. In a study with premenopausal patients, Osmers et al. found that the risk of malignancy increases with increasing mass size in simple cysts ${ }^{(14)}$. Although we determined the sensitivity of cut-off value of DePriest score of 5 points for the differential diagnosis of malignancy as $100 \%$, the scores were higher in 20 patients with benign pathology. This indicates that a different cutoff value needs to be investigated with further studies in order to reduce the false positivity rate.

In our study, the minimum (5.8), maximum (1719), median (26.1), and mean (108 \pm 245$)$ values for CA 125 were also determined. While in the benign group ( $n: 88)$, the mean value for CA 125 was $59.1 \pm 134.3$, and in the malignant group ( $n: 28)$ it was 261.4 \pm 407 . In the malignant group, the CA 125 value was significantly higher $(p=0.002)$ than the benign group. In a study conducted by Tuxen, CA 125 was found to be normal in $10-20 \%$ of patients diagnosed with Stage 1 ovarian cancer. For this reason, CA 125 alone is not considered sufficient in screening for ovarian cancer, and it is recommended to evaluate the patient with physical examination and ultrasonographic findings ${ }^{(15)}$. In the study with 158 patients in 2003, Torres et al. foundi ts sensitivity as 51 and its specificity as 88 percent. Positive and negative predictive values were not specified in the study ${ }^{(16)}$. In a study with 140 patients in $2003 \mathrm{Ma}$ et al. determined the sensitivity, spcificity, positive, and negative pre- 
H. Kaya et al, Comparison of CA 125, CA 72-4, Risk of Malignancy Index and DePriest Scoring System in the Differentiation Between Benign an Malignant Adnexal Masses

dictive values for CA-125 test as 73, 85.7, 80.7 and $79.5 \%$, respectively ${ }^{(17)}$. In a study by Morgante et al. sensitivity, specificity, positive and negative predictive values of CA-125 test were found as $74,95,82$ and $92 \%$, respectively ${ }^{(18)}$. In their study with 152 patients in 2000, Manjunath et al. found the sensitivity, specificity positive and negative predictive values of CA-125 test as $77,87,91$, and $70 \%$, respectivelyt ${ }^{(19)}$. In the study of Jacobs et al. with 143 patients in 1990 , sensitivity, and specificity of CA-125 test were

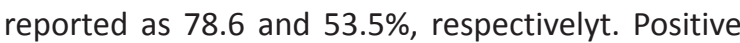
and negative predictive values were not specified in the report ${ }^{(20)}$. In our study, for CA 125 we found sensitivity $(71.4 \%)$, specificity $(71.5 \%)$, positive $(44.4 \%)$, and negative $(88.7 \%)$ predictive values, as indicated. Except for the low sensitivity rate found by Torres et al. the data of our study are compatible with the literature data.

In the malignant group, the CA 125 value was significantly higher $(p=0.002)$ relative to the benign group. In a study by Anastasi et al comparing 50 healthy women, and patients with benign ovarian tumors $(n=17)$, ovarian endometriomas $(n=57)$ and ovarian cancer $(n=39)$, serum CA 125 concentrations were found to be higher in patients with endometriomas and ovarian cancer, whille they were within normal limits in patients with benign ovarian masses ${ }^{(21)}$. In our study, higher CA 125 levels were detected in 16 of 19 patients with endometriomas. Therefore, it was concluded that CA 125 alone was not sufficient to predict malignancy in ovarian cancer. Endometrioma is an important disease that makes us look for another method or molecule to be used in the differential diagnosis of ovarian cancer. The blood tests of a patient who had a borderline seromucnous tumor as a result of pathology were sent to the laboratory twice on two different days and a significant difference was observed between CA125 values $(231 \rightarrow 49)$. Likewise, although the blood tests of two other patients diagnosed with serous cystadenoma and leiomyoma were sent to the laboratory twice on two different days, the results were close to each other $(6 \rightarrow 5,8$ and $12 \rightarrow 10)$. This shows us that there may be different underlying mechanisms in malignant masses.

In 1995 study of Guadagni et al., the specificity of CA 72-4 for ovarian cancer was found to be $>95 \%$ and when it was combined with CA 125, it was stated that its sensitivity increased without any change in its specificity ${ }^{(22)}$. In the study by Steven J. Skates et al., preoperative sensitivity rates for early stage disease were $45 \%$ for CA $125,67 \%$ for CA 125 and CA72-4, 70\% for CA 125, CA72-4 and M-CSF, and for all four parameters, including sonography a sensitivity rate of $68 \%$ was determined. It was reported that the preoperative combination of CA 125, CA72-4 and M-CSF increases the sensitivity rate from $45 \%$ to $70 \%$ in early-stage disease. Evaluation of CA72-4 together with pelvic examination, USG and serum CA 125 has been reported to be beneficial in distinguishing between malignant and benign pelvic masses ${ }^{(23)}$. In our study, we found the sensitivity (28.6\%), specificity (89.8\%), positive (47.1\%), and negative (79.8\%). predictive values of CA72-4, as indicated In a study conducted by Anastasi et al., sensitivity, specificity, positive and negative predictive values for CA72-4 were reported as $84,89,67$, and $96 \%$, respectively (21). It was also stated that there was a significant difference in CA72-4 values between ovarian cancer and endometioma patients. In our study, we detected CA72-4 above the cut -off value in 5 of 19 patients who had endometrioma. The low sensitivity of CA72-4 can be explained by the higher number of endometrioma cases in our study. Although the sensitivity, and specificity of CA72-4 were $28.6 \%$ and $89.8 \%$ which appears to be statistically significant $(p=0.017)$, in malignant-benign distinction of adnexal masses it is not sufficient for screening alone. When combined with CA 125 , there is no change in sensitivity and only some increase in specificity was noted.

\section{CONCLUSION}

Due to its low sensitivity, CA72-4 was not sufficient to predict the pathology outcome in adnexal masses. Significant efficacy of RMI and CA 125 has been observed. As a result of the study, it was observed that DePriest scoring system has gtreater diagnostic efficacy than CA 125, CA 72-4 and RMI scoring system when it was evaluated alone in the prediction of malignancy. However, further studies are needed to be more effective in our clinical practice in predicting pathology results by using them alone or in combination. 


\section{Acknowledgement}

I would like to thank to Assoc. Dr. Banu işBíLEN BAŞOK and Dr. Emre YALÇINKAYA for their guidance in biochemical tests, and the Editorial Board of The Medical Journal of Bakırköy thet will evaluate my manuscript for publication.

Ethics Committee Approval: All authors have not declared any conflict of interest.S.B. Approval was obtained from the Clinical Research Ethics Committee of Istanbul Medeniyet University Göztepe Training and Research Hospital (23.09.2014 / 2014/0142).

Conflict of interests: All authors have not declared any conflict of interest.

Funding: Two thousand one hundred and thirty- four Turkish Liras were granted from Istanbul Medeniyet University Scientific Research Projects Coordination Unit as a financial support to purchase CA 125 and CA72-4 laboratory kits.

Informed Consent: Since it was a prospective study, enlightened voluntary consent form was signed by all patients.

\section{REFERENCES}

1. DiSaia PJ, Creasman WT. Clinical gynecologic oncology. 6th ed. 2002. p. 259. https://doi.org/10.1016/B0-32-301089-X/50013-1

2. Ayhan A, Durukan T, Günalp S. Temel kadın hastalıkları ve doğum bilgisi. 2008. p. 987.

3. Ayhan A, Gültekin M, Dursun P. Tekxtbook of gynecological oncology. Ankara: Güneş Publishing; 2009. p. 312

4. Berek SJ. Berek and Novak's gynecology. 2007. p. 1457-9.

5. Oztoprak B, Karakus S. Value of multiple computed tomography criteria for prediction of malignancy in patients with ovarian mass. Gynecology Obstetrics \& Reproductive Medicine. 2018;24(1):42-6. Available from: http://gorm.com. tr/index.php/GORM/article/view/706/666 https://doi.org/10.21613/GORM.2017.706

6. Kabawat SE, Bast RC Jr, Welch WR, Knapp RC, Colvin RB. Immunopathologic characterisation of a monoclonal antibody that recognizes common surface antigens of human ovarian tumors of serous, endometrioid and clear cell types. Am J Clin Pathol. 1983;79(1):98-104. https://doi.org/10.1093/ajcp/79.1.98

7. Hasholzner $U$, Baumgartner $L$, Stieber $P$, et al. Clinical significance of the tumour markers CA 125II and CA 72-4 in ovarian carcinoma. Int J Cancer. 1996;69(4):329-34. https://doi.org/10.1002/(SICI)1097-0215(19960822)69:4<329::AIDIJC16>3.0.CO;2-0

8. Yamamoto $\mathrm{Y}$, Yamada R, Oguri $\mathrm{H}$, et al. Comparison of four malignancy indices in the preoperative evaluation of patients with pelvic masses. Eur J Obstet Gynecol Reprod Biol. 2009;144(2):163-7. https://doi.org/10.1016/j.ejogrb.2009.02.048

9. Lerner JP, Timor-Tritsch IE, Federman A, Abramovich G. Transvaginal ultrasonographic characterization of ovarian masses with an improved, weighted scoring system. Am J Obstet Gynecol. 1994;170(1 Pt 1):81-5. https://doi.org/10.1016/S0002-9378(94)70388-4
10. Deregözü A, Uzun I, Karahasanoğlu A, Yücel O. Bir eğitim ve araştırma hastanesinde opere edilen benign adneksiyal kitleli olguların analizi. Bakırköy Tıp Dergisi. 2018;14:40-3. Available from: http://cms.galenos.com.tr/Uploads/Article_20005/ BTD-14-40.pdf https://doi.org/10.5350/BTDMJB.20151223113440

11. Obeidat BR, Amarin ZO, Latimer JA, Crawford RA. Risk of malignancy index in the preoperative evaluation of pelvic masses. Int J Gynaecol Obstet. 2004;85(3):255-8. https://doi.org/10.1016/j.ijgo.2003.10.009

12. Andersen ES, Knudsen A, Rix P, Johansen B. Risk of malignancy index in the preoperative evaluation of patients with adnexal masses. Gynecol Oncol. 2003;90(1):109-12. https://doi.org/10.1016/S0090-8258(03)00192-6

13. Tingulstad S, Hagen B, Skjeldestad FE, Onsrud M, Kiserud T, Halvorsen T, Nustad K. Evaluation of a risk of malignancy index based on serum CA 125, ultrasound findings and menopausal status in the pre-operative diagnosis of pelvic masses. Br J Obstet Gynaecol. 1996;103(8):826-31. https://doi.org/10.1111/j.1471-0528.1996.tb09882.x

14. Osmers RG, Osmers M, von Maydell B, Wagner B, Kuhn W. Preoperavite evaluation of ovarian tumors in the premenopouse by transvaginosonography. Am J Obstet Gynecol. 1996;175(2):428-34. https://doi.org/10.1016/S0002-9378(96)70157-6

15. Tuxen MK, Soletormos G, Dombernowsky P. Tumor markers in the menagement of patients with ovarian cancer. Cancer Treat Rev. 1995;21(3):215-45. https://doi.org/10.1016/0305-7372(95)90002-0

16. Torres JCC, Derchain SFM, Faundes A, Gontijo RC, Martinez $E Z$, Andrade LA. Risk of malignancy index in preoperative evaluation of clinically restricted ovarian cancer. Sao Paulo Med J. 2002;120(3):72-6. https://doi.org/10.1590/S1516-31802002000300003

17. Ma S, Shen K, Lang J. A risk of malignancy index in preoperative diagnosis of ovarian cancer. Chin Med J (Engl). 2003; 116(3):396-9. PMID: 12781045

18. Morgante G, la Marca A, Ditto A, De Leo V. Comparison of two malignancy risk indices based on serum CA 125 , ultrasound score and menopausal status in the diagnosis of ovarian masses. Br J Obstet Gynaecol. 1999;106(6):524-7. https://doi.org/10.1111/j.1471-0528.1999.tb08318.x

19. Manjunath AP, Pratapkumar, Sujatha K, Vani R. Comparison of three risk of malignancy indices in evaluation of pelvic masses. Gynecol Oncol. 2001;81(2):225-9. https://doi.org/10.1006/gyno.2001.6122

20. Jacobs IJ, Oram D, Fairbanks J, Turner J, Frost C, Grudzinskas JG. A risk of malignancy index incorporating CA 125, ultrasound and menopausal status for the accurate preoperative diagnosis of ovarian cancer. $\mathrm{Br} J$ Obstet Gynaecol. 1990;97(10):922-9. https://doi.org/10.1111/j.1471-0528.1990.tb02448.x

21. Anastasi E, Granato T, Falzarano R, et al. The use of HE4, CA 125 and CA72-4 biomarkers for differential diagnosis between ovarian endometrioma and epithelial ovarian cancer. J Ovarian Res. 2013;6(1):44. https://doi.org/10.1186/1757-2215-6-44

22. Guadagni $F$, Roselli $M$, Cosimelli $M$, et al. CA72-4 serum marker-a new tool in the management of carcinoma patients. Cancer Invest. 1995;13(2):227-38. https://doi.org/10.3109/07357909509011692

23. Skates SJ, Horick N, Yu Y, et al. Preoperative sensitivity and specificity for early-stage ovarian cancer when combining cancer antigen CA-125II, CA 15-3, CA 72-4, and macrophage colony-stimulating factor using mixtures of multivariate normal distributions. J Clin Oncol. 2004;22(20):4059-66. https://doi.org/10.1200/JCO.2004.03.091 